Jeremy Howard

University of St Andrews

jch2@st-andrews.ac.uk

\title{
VLADIMIR MARKOV'S STAIRCASE IN MOONLIGHT: QUESTIONS OF RUSSIAN MODERNIST CHINOISERIE AND SINOLOGICAL MODERNISM
}

\begin{abstract}
Vladimir Markov (Voldemārs Matvejs) (1877-1914) avoided the '-ism' plague in his writing. Yet he can be seen as orientalist, primitivist, archaist and modernist. All his published essays refer to art from China and it is this abiding concern with Chinese aesthetics that is the subject here. While leading towards the arguments developed in Chinese Flute [Svirel' Kitaya] (1914), this paper also analyses Markov's interpretation and examples of artistic principles he determined as Chinese, in his other studies. Thus we move from his concern for poetic structure, licence and appearance to 'non-constructiveness', 'chance', refinement, imitation, 'free creativity', collation of materials, framing, symbol and timbre. In essence these comprise an argument for ways to reform contemporary European art through core analysis of what comprises the making and stuff of art. While Markov's gaze is global, as, for instance, his investigations into African, Oceanic and North Asian art reveal, and while, simultaneously he can be described as a Byzantinist for all his concern for icons, these attributes sit alongside what we can view as modernist chinoiserie and sinological modernism. Our enquiry turns to this identification, examining how Markov's approach contextualises with developments in chinoiserie and sinology in the early twentieth century, and thereby positing relationships with the interpretational work of, for example, Vasiliy Alekseyev, Nikolay Vinogradov and Leopold Staff, as well as a range of early-twentieth-century Russian visual artists.
\end{abstract}

Keywords: Vladimir Markov, Chinese poetry, kitaevedenie, sinology, chinoiserie, modernism.

\section{Introduction}

In January 1914 a book entitled Chinese Flute (henceforth referred to by its Russian title Svirel' Kitaya [Свирель Китая]) by Vladimir Markov (pseudonym of Voldemārs Matvejs) and his friend Vyacheslav Yegorev was published by the Union of Youth (Soyuz Molodezhi [Союз молодежи]) society of artists in St Petersburg. It included thirty-one poems in Russian translation (or 'transposition') by twenty-three poets of various dynasties, an essay by Markov introducing the history and principles of Chinese poetry and nine separate notes on the authorship of some of the poems. Such an exercise in bringing Chinese literature 
and an understanding of Chinese prosody to a Russian audience had never before been undertaken. Yet for all its groundbreaking role and its intensively researched and finely elaborated critical appraisal of Chinese aesthetics Svirel' Kitaya remains absent from the historiography of Russian kitaevedenie [китаеведение] (sinology), let alone non-Russian sinology, east-west cultural exchange and modernist art. To a few the silence is deafening, to most the silence is unheard. ${ }^{1}$ What follows then is a study of void.

The literature on Laurence Binyon's pioneering appreciation of art from China or Ezra Pound's Sinophilia is extensive. ${ }^{2}$ Though outstripped by Japonism, it has become something of a fashion to explore the contribution of China to the development of modernism, be that global or the Euro-American models that still hold sway for some. While I am sure there will be studies of Russian late-nineteenth and early-twentieth century interchange with Chinese culture (and vice versa) of which I am unaware, at least at first glance there would seem to be relatively few which have been aimed at non-Russian or non-Chinese audiences. ${ }^{3}$

Why should a relatively young Latvian visual artist, a student of painting at the St Petersburg Imperial Academy of Arts, be writing about Chinese literature, its history and rules? This paper seeks to supply a few answers. To do this as fully as presently possible Markov's study of Chinese poetry is here contextualised in four ways: 1) in terms of his own probing of Chinese aesthetics; 2) in terms of Russian concern for Chinese culture; 3) in relation to Euro-American modernism; 4) in regard concepts of orientalism and primitivism.

\section{Markov's Staircase in the Moonlight}

The back cover of the second issue of Soyuz Molodezhi, the eponymously titled journal of the Union of Youth group which Markov was spearheading at the time of its publication, announced Svirel' Kitaya as forthcoming. This was June 1912. When it finally appeared in early 1914, the volume was to include six Chinese poems which had appeared in the first two numbers of the journal immediately after the two parts of Markov's manifesto for modern art entitled 'Principles of the New Art'. Together with his subsequent study of artistry, Faktura (1914), this was to reveal a sensitivity to the lessons to be learned from Chinese concepts of beauty. In some respects as he skits over whole trends in very few words, Markov made sweeping generalisations about 'Chinese' principles and thus falls into the trap of late nineteenth-century/early twentieth-century European-American orientalists with their constructions of an homogenous China.

1 For a major study of the unheard silence, see Sullivan 1997. For slight studies which moot the deafening silence, seе Ковтун 1979; Howard, Bužinska, Strother 2016; Howard 1992; Strala 1988.

2 Markov's interest in Asian art coincided with that of Laurence Binyon, Keeper of Oriental Prints and Drawings at the British Museum, London. See, for example, Binyon 1911.

3 Ellen Johnston Laing has revealed some aspects of the pre-First World War Sino-Russian visual art exchange (Laing 2010). 
But where they had mostly contrived to set the art of the Chinese lands apart from that of their own, Markov possesses none of their exoticism, instead seeing fruitful relationships and potential for learning. Furthermore, he moves between media and era with an overarching intent to pick out distinguishing phenomena and traits that comprise the very stuff of genuine art, just as he does with some Byzantine, African, Oceanic, north Asian and European 'primitives'. He inevitably fabulates but he does so through extremely diverse, concrete example and he does so from what he sees as a position of contemporary European inferiority.

Even the most cursory survey of Markov's publications between 1910 and 1914 reveals an omnipresent modernist sinological slant. In 'Russian Secession', his first manifesto for the Union of Youth and Russian avant-garde art, he contextualises it with prominent 'oriental' aesthetic values, not only by drawing attention to the spiritual and formal conventions of

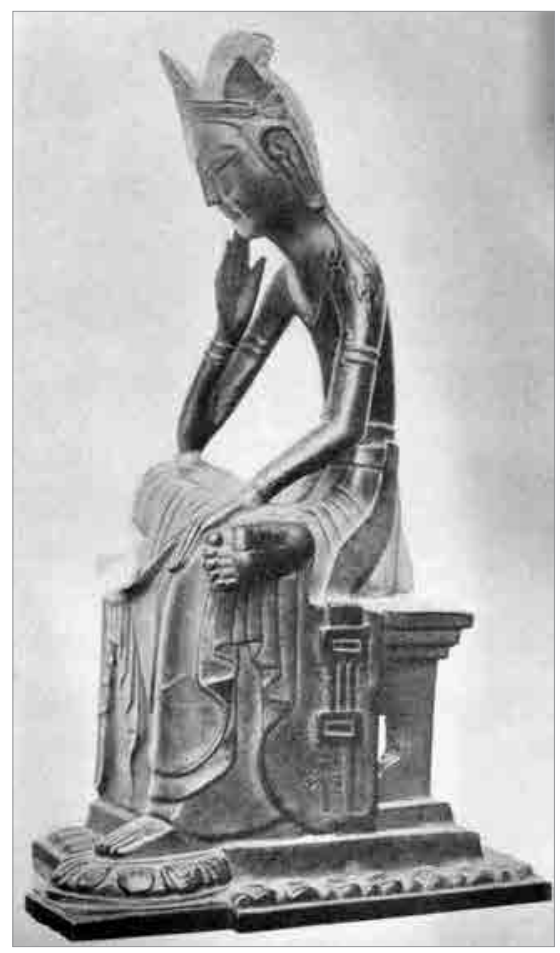

I1l. 1. Unknown Artist. Bodhisattva (Kannon). Bronze, gold-plated. $38.3 \mathrm{~cm}$. $7^{\text {th }}$ century. Tokyo National Museum. Buddhist art, but also urging artists to develop their 'own calligraphy', as 'in the East line is impassioned and infinite in its variations. India, China, Assyria, Byzantium - every country and people breaks lines according to their taste and own way.' (Howard, Bužinska, Strother 2016: 160). Two years later, in his second manifesto, 'Principles of the New Art', he was more explicit about the qualities of art from China that he extolled, while also acknowledging that it had lost its acuity in modern times (Союз молодежи, 1-2 (1912); Howard, Bužinska, Strother 2016: 165-178). In essence the qualities came down to what he termed the principles of 'non-constructiveness' and 'free creativity' which he opposed to rational, constructiveness of European, postRenaissance art. He found this in what he considered a sixth century Chinese Bodhisattva sculpture, with its non-anatomical treatment of the figure, its beauty in dissonance, interplay of heavy and light, linear rhythm all showing freedom from science and nature (see Howard, Bužinska, Strother 2016: 26-27). ${ }^{4}$ (Ill. 1) Perhaps most significantly, he also revealed it through the Chinese appreciation

4 Varvara Bubnova, Markov's partner, noted that 'Markov bought Münsterberg's richly illustrated book on Chinese art... the reproduction of the Buddhist sculpture was probably taken from Münsterberg' (Howard 1992: 120). The image appeared in Münsterberg (1910: 143). The bronze sculpture is recognised as Kannon (Guanyin), the female aspect of Bodhisattva Avalok- 
of aleatoric art. His probing of the value of chance derived from analysis of Chinese examples, i. e. the wind blown bell chimes of Chinese village pagodas, the arbitrary copper oxide glazing of Chinese vases, and:

the chance, nonsensical collation of spots and lines of Chinese letters... the Chinese loves when a line unconsciously and beautifully coils like a ganglionshaped plant. Even the capricious forms of clouds seem jejune to him and he tries all the more to enhance their whimsicality. Unlike the Greek, the Chinese cannot honestly and assiduously repeat some meander or geometric form many times. If he takes a form he unbinds it and repeats it in an infinite number of arbitrary combinations. This is in complete contrast to our academism which by its very nature does not tolerate arbitrariness anywhere and is now attempting to abolish it.

Yes, the Orient loves accidentalness, searching, catching and exploiting it in every possible way. The Chinese, for example, sings that a woman's eyebrows are long and black like the wings of black swallows in flight. In the tree they fly over he sees a harp upon whose strings the wind weeps. For him, falling snow is a cloud of white butterflies descending to earth. ${ }^{5}$

Chance opens up whole worlds and begets wonders. The existence of many marvellous, unique harmonies and scales, and the enchanting overall tone of Chinese and Japanese pictures, relies solely on their appearance by chance. They were appreciated by a keen eye and fixed. (Howard, Bužinska, Strother 2016: 169-170).

For Markov chance, the absurd and free creativity could bring forth the Chinese 'swans of other worlds' (Howard, Bužinska, Strother 2016: 176), deep inner resonances, in terms of artistic expression. Furthermore, they could combine with unconscious plagiarism: 'In China, where the people are raised on art and educated in beauty, what is imperiously demanded of artists is that they produce variations on three-thousand year old art. Imitation and free copying are very highly valued.' (Howard, Bužinska, Strother 2016: 175). Such appreciation of imitation leads towards Duchampian aleatoriness and use of the ready-made (e. g. 'Three Standard Stoppages', 1913-14, and 'Readymade malheureux', 1919).

Markov was to further develop his sinological modernism as he began to deepen his enquiry into 'the principles of creativity', initially with his essay on artistic facture (Марков 1914; Howard, Bužinska, Strother 2016: 179-216). There, as he looked to elucidate the constitution of the 'timbre', 'noise' or 'artistry' of art, he brought in a new range of Chinese examples to help probe the different characteristics of faktura. Thus whether it was in his analysis of material, material inter-relations, frame, patina, surface or symbolic imitation, he guided his

itesvara and is considered seventh century. Found in the Hōryū-ji Temple (Nara, Japan) and now in Tokyo National Museum it blends Chinese and Japanese traditions of Buddhist art.

5 Here Markov refers to lines from three Chinese poems which appeared in Russian translation (by Vyacheslav Yegorev), at the end of part one of his article as it appeared in Союз молодежи $(1,1912: 15-17)$. The first citation is from 'Gifts of Love' (unknown author, $18^{\text {th }}$ century), in which the 'woman's eyebrows were dark and long like the wings of swallows in flight'. The second, 'Autumnal' (Lo Chang Nai, nineteenth century), 'sings' of the twigs of a tree being a harp played by the wind. The third, 'Winter's coming' (Su Shi (Dongpo), eleventh century), has snow falling unheard to earth as a cloud of white butterflies. The poems were republished in Егорьев, Марков (1914): 63, 80 and 87). 
reader by Chinese ways. Suffice it to mention here that he appreciated the plastic potential of hair ('China even makes partings ornamental'), the coherence of silk picture and frame in China, the running of colour in Chinese painting ('it flows like a waterfall or stream') and that 'China requires that an artist draws mountains in such a way that they seem to breathe'. He concludes the penultimate section, titled 'Collation of Materials', with an analysis of how materials can be 'enslaved' to one another. In so doing he moves from the assemblages of Byzantine icons to the inlays of classical sculpture and then to a poem by Tang dynasty master Li Bai (Li Tao Po). In it he claims 'deep philosophical thought is absent. There is only painting with materials... the poet gives an assortment of delicately glimmering materials that are covered with the moist shine of the dew. With such a collation we are able to acquire a special faktura of sheen that it would have been impossible to get with just one material' (Howard, Bužinska, Strother 2016: 210-211). He thereby ignores its sense of nighttime courtesan lament.

The poem in question was to also appear in Svirel' Kitaya where it was titled 'Staircase in Moonlight' [Lestnitsa pri lunnom svet/ Лестница при лунном свете] (Егорьев, Марков 1914: 49). Given its significance for Markov it is worth reproducing Yegorev's Russian version (which came from Hans Bethge's German transposition (Bethge 1907: 31), with its original layout, and providing an English translation from it:

\section{Лестница при лунном свете}

Из белого, прозрачного нефрита

Подымается лестница,

Обрызганная росой...

И в ней светится полная луна...

Все ступени мерцают лунным светом.

Царица в длинных одеждах

Поднимается по ступеням

И роса, переливаясь,

Мочит края благородных покровов.

Она идет к павильону,

Где в лунные лучи

Прядут свою ткань.

Ослепленная, останавливается она на пороге.

Ея рука тихонько спускает жемчужный занавес

И ниспадают чудные каменья,

Журча, как водопад,

Пронизанный лучами солнца.

И внимает царица журчанию

И с грустью смотрит на лунный свет,

На осенный лунный свет,

Льющийся сквозь жемчуг.

... $\quad$ И долго с грустью смотрит на лунный свет. 


\section{Staircase in Moonlight}

Of white, transparent jade

Ascends a staircase,

Dew-sprinkled...

And in it the full moon is reflected...

All the steps glint with the moonlight.

The queen, in her long robes

Climbs the steps

And the dew, flowing,

Moistens the hem of the noble cloaks.

She walks to a pavilion

Where the moon rays

Spin their cloth.

Dazzled she stops on the threshold.

Her hand slowly lowers a pearl curtain

And marvellous stones fall,

Murmuring, like a waterfall

It is pierced by sunbeams.

And the queen heeds the murmur

And with sadness looks at the moonlight,

At the autumn moonlight,

Gushing through pearls.

... And, for a long time, she sadly watches the moonlight.

These twenty-two lines would seem extremely wordy and free for a Chinese quatrain in which each of the four lines has just five characters. Its pentasyllabic form, anthologised in 1705, some thousand years after its creation during the Tang dynasty, is that which its first translators worked from:

\section{玉階怨 \\ 玉階生白露 \\ 夜久侵羅襪 \\ 卻下水晶簾 \\ 玲瓏望秋月}

(Bradbury: n.d.).

Markov acknowledges the translation issues in Svirel' Kitaya (Егорьев, Марков 1914: XVI) in relation to a very similar 'moonlight reminiscence' quatrain by Li Bai, i. e. his famous 'Quiet Night Thoughts'. So while the translation particularly suits his concern with the faktura of sheen, it is of limited use for the rules of Chinese prosody (such as metre, caesura, rhyme, stress, parallelism, strophe, repetition and pictorial elements) that he identifies as key. Despite this loss of the distinctive relationship between word and image in Chinese poetry Markov's and Yegorev's translation has found favour in Russian sinology, with the director of the Institute of Oriental Cultures and Antiquity at the State Uni- 
versity of the Humanities in Moscow, Ilya Smirnov, noting in an article dedicated to analysing translations of the 'Staircase in Moonlight' poem:

The history of its transposition into Russian language would seem to commence from the Svirel' Kitaya anthology, the translators of which, Yegorev and Markov, were the first to acquaint our public with examples of classic Chinese poetry in that volume. This anthology has acquired a bad reputation and has often been criticised extremely maliciously... Let me risk pronouncing an idea that is seditious for any sinologist. If you want to consider Chinese poetry classics in terms of its tightness, polysemantics, outer simplicity combined with an almost fathomless depth of ideas, then does it not make sense to remember the ill-starred and frequently ridiculed attempts of Yegorev and Markov who in the early twentieth century transformed a Chinese quatrain into a rather extensive Russian text? For, though it might not always be precise, with this they expressed not just a gloss of the concept but have also divined that which lies behind the words. It is true they did this in a poor and clumsy way but, as we can now see, in the very attempt there was a glimmering of something (Смирнов: 2007; author's translation).

Such relatively recent appraisal departs from that given by Markov's contemporary, Vasiliy Alekseyev, who in 1923 noted the following with regard Svirel' Kitaya: 'a relatively large book, with a foreword, which, in attempting to teach the reader about the structure of Chinese verse, and its system, simulates erudition. This book can produce an effect on the reader, and hence the anthology requires a couple of words' (Алексеев: 2000, 30-31). Thereafter Alekseyev gave what he considered a literal translation of Tang poet Meng Hao-jan's verse that Yegorev had translated with the title 'Awaiting a Friend' (Егорьев, Марков: 1914, 39). Yegorev's wordiness and departure from the original was regarded by Alekseyev as an example of pretentious fabrication rather than direct translation, something he considered being pioneered by his own volume. And yet, compared to the dry 'literal' rhyming translations by Alekseyev and his student Yulian Shchutskiy, there is, as Smirnov notes, some essential glimmer in Svirel' Kitaya's moonlit staircase. This then is Shchutskiy's 1922 Russian translation of 'Staircase in Moonlight', now retitled 'Longing on Jasper Stairs' (alongside my attempt at an anglicised interpretation of it):

\section{Тоска у яшмовых ступеней}

Я стою... У яшмовых ступеней Иней появлется осенний. Ночь длинна-длинна... Уже росой Мой чулок охвачен кружевной. Я к себе вернулась и, печальна, Опустила занавес хрустальный; Но за ним я вижу: так ясна Дальняя осенняя луна!

\section{Longing on Jasper Stairs}

I stand... On jasper stairs As autumn rime appears The night is ever so long My stockings laced with dew on. Composing myself, and hurting, I lowered the crystalline curtain But beyond it I see as if clean The distant autumn selene!

(Щуцкий: 1922)

Who are we to decide between Yegorev and Shchutskiy? Or, for that matter, between their Russian attempts and, for instance, Hans Bethge's, Judith Gautier's, 
Ezra Pound's, Arthur Cooper's, Andrew W.F. Wong's German, French and English versions. ${ }^{6}$ Let us suspend judgment and instead place Yegorev and Markov's endeavours alongside the creative Chinese interpretations of, say, Pound. ${ }^{7}$ Furthermore, it can be seen to lay the ground for outstanding examples of Russian and Polish sinological modernist poetry, i. e. Nikolay Gumilev's anthology of eleven transpositioned Chinese poems Porcelain Pavilion (Гумилев: 1918) and Leopold Staff's 1922 volume of 'Chinese' verse which even carried the same title: Fletnia Chińska (Staff: 1922).

\section{Russian Kitaevedenie, Modernist Chinoiserie and Sinological Modernism}

Assisted by Yegorev, Markov's probing of the principles of Chinese art and poetry coincided with a surge in Russian concern for Chinese culture. While this partially derived from the Tsarist regime's political and economic interests in the Far East, it was most closely connected with a heightened scientific and artistic appreciation of Chinese civilisation. ${ }^{8} \mathrm{~A}$ few examples of the latter stand out for their relationship to Markov's mix of chinoiserie and sinological modernism. With links between them, and no hard boundaries dividing them, they can be classified in the following way: literary interpretations ('scientific' and 'creative'); collections; displays; and visual interpretations ('creative'). Together they comprise the Russian historical performance of Chinese art and hence it is worth at least introducing them. For all the Russian historiography of its kitaevedenie, it would appear that the sources closest to Markov's critical-aesthetic-historical terms of reference, and in particular those of his moment, are largely overlooked. Three such works can be mentioned.

First, Wilhelm Grube's Spiritual Culture of China: Literature, Religion, Cult (Духовная культура Китая. Литература, религия, культ) which was published in St Petersburg in 1912, as a Russian translation (by P. O. Efrussi) from several German texts by the author (Грyбe: 1912). It included several photographs and poems (creatively transposed into Russian by Andrey Koltonovskiy). Grube had died in 1908 but he had a long-standing connection with the Russian capital, having been born and trained as a sinologist there before settling in Germany.

${ }^{6}$ Concerning English translations, see, for example: Bradbury: n.d. Bradbury prefers Pound's title 'The Jeweled Stairs Grievance' and indicates the verse's place in western modernist literature (see Pound: 1915).

7 Pound's 'The Jeweled Stairs' Grievance' (Pound 1915: 13) reads:

The jewelled steps are already quite white with dew

It is so late that the dew soaks my gauze stockings,

And I let down the crystal curtain

And watch the moon through the clear autumn.

8 Of particular note in this regard is artist and physician Pavel Pyasetskiy's (Piassetsky) textual and visual record of his experience of Chinese culture in the mid-1870s (this having been published in Russian, French and English editions between 1880 and 1884, е. g. Пясецкий: 1880-81). 
Markov's knowledge of German also meant that he was to plagiarise parts of Grube's earlier, monumental Geschichte der chinesischen Litteratur (Leipzig, 1902) for his analysis of 'stress' and 'parallelism' in Svirel' Kitaya.

Second, writing for Apollon in May 1914, the young art critic Vsevolod Dmitriev produced a study of 'Chinese realness' (Китайская реальность) in which he enthusiastically argued for an appraisal of Chinese art in terms of its refined formal 'non-resistance' (непротивление). This was a term he borrowed from the Russian translation of Henri Borel's creative interpretation of Lao-Tze's Taoist 'Wu Wei' effortlessness, as opposed to the 'struggle' (борение) at the heart of European art with its qualities of passion (страстность) (Дмитриев 1914: 24-25). ${ }^{9}$

Third, Pavel Gladkiy, a member of the Russian Society of Orientalists and the Royal Asiatic Society of Great Britain, published Chinese Art. An Historical Introduction (Китайское искусство. Историческое введение) in Harbin in 1915. In this small booklet the author gave a sweeping yet critically informed and per-

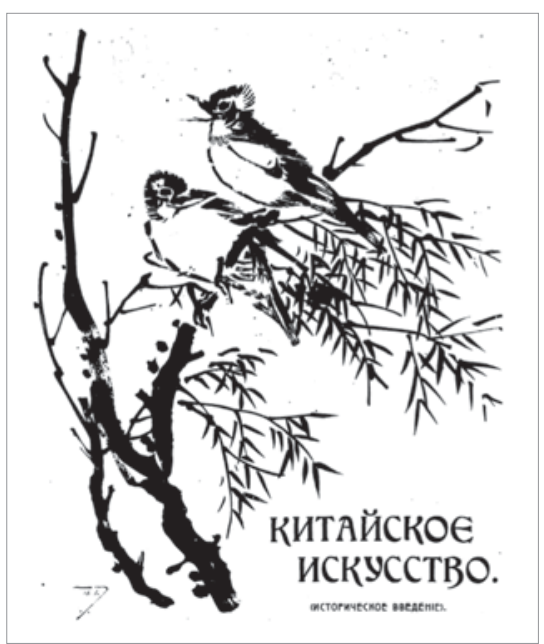

I11. 2. Unknown Artist. Cover. Pavel Gladkiy. Chinese Art. An Historical Introduction. Harbin. 1915.

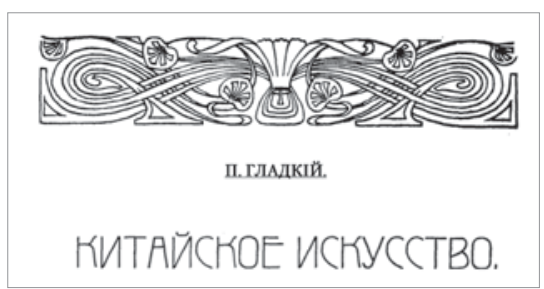

I11. 3. Unknown Artist. Vignette, p. 3. Pavel Gladkiy. Chinese Art. An Historical Introduction. Harbin. 1915 ceptive overview of the development of principle qualities of art in China. He reserved his most ardent criticism for the empiricist approach and exoticist neglect afforded it by Europeans. His cover featured a black-and-white drawing of two young birds, one singing, perched on a bending willow tree branch. (Ill. 2) The flat, abstracted style of the image correlates with the Art Nouveau interlaced linear floral pattern of the vignette that then introduces Gladkiy's text. (Ill. 3)

Appearing between 1912 and 1915, these three examples show both the currency of Markov's Russian sinophilia and the vital relationship between the literary and visual artistic principles he discerned. In terms of their Illustrations, it is Dmitriev's work, published in the month of Markov's death, where images of Chinese paintings of different eras from Russian collections appear, i. e. those

9 Dmitriev also suggested that a third way for the artistic conveyance of 'real' could be discerned, i.e. that of 'transfigurative' (преображенная) realness in Russian icons (Дмитриев 1912: 25). Borel's book had originally appeared in Dutch in 1895 and soon thereafter in a number of English translations. 


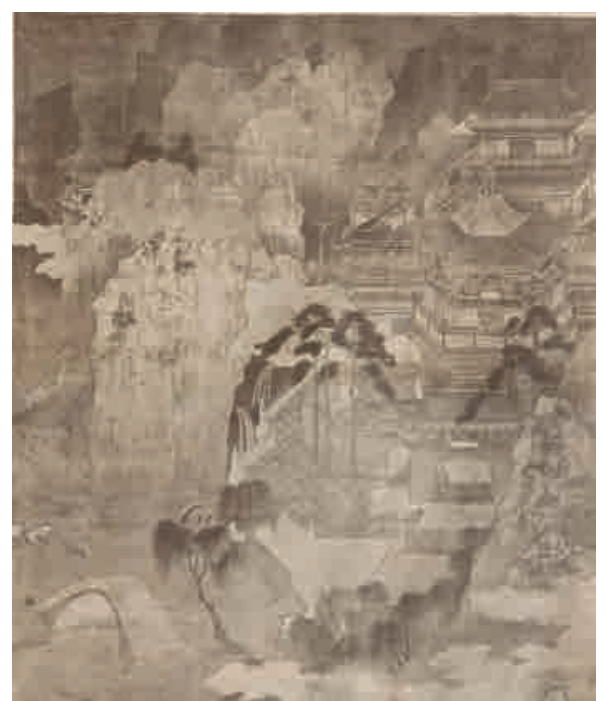

Ill. 4. Li Zhaodao. Jiucheng Palace. Painted silk. $36 \times 30 \mathrm{~cm}$. c. early $8^{\text {th }}$ century

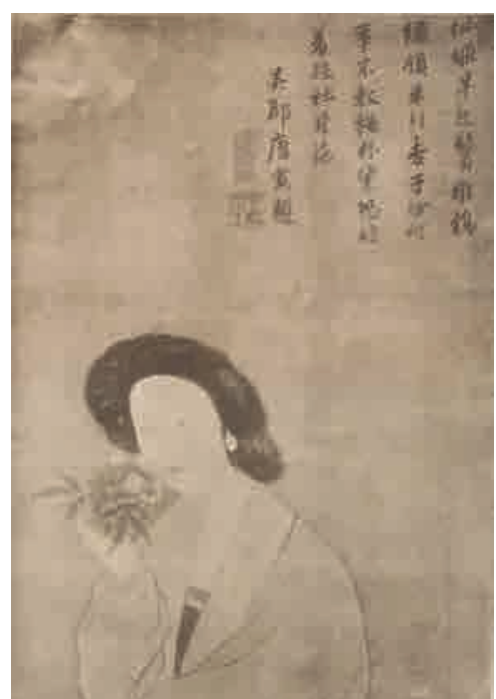

Ill. 5. Tang Yin. A Beautiful Woman with Peonies. Painted silk. $74 \times 51 \mathrm{~cm}$. Early $16^{\text {th }}$ century

of the Paris-based Viktor Golubev (Victor Goloubew) and the Muscovite Sergey Shchukin. Golubev's immersion in oriental art was without European parallel and at this stage included his crucial involvement in groundbreaking exhibitions at the Cernuschi Museum in Paris as well as his responsibility for the pioneering illustrated de-luxe annual Ars Asiatica. The first volume of the latter appeared in early 1914 and was dedicated to recording and analysing La Peinture Chinoise, an exhibition of Chinese painting that had taken place in May-June 1912 (Chavannes, Petrucci: 1914). It provided Dmitriev with all but one of his seven reproductions, four of which were drawn from Golubev's collection: Li Zhaodao's kaleidoscopic 'Jiucheng Palace' (IIl. 4), Wang Shen's paired eating and sleeping 'Eagles, A Beautiful Woman with Peonies' by Tang Yin (Ill. 5) and 'Portrait of an Emperor' by an unknown artist. Thus the Tang, Song, Ming and Qing dynasties were represented, as were distinctive Chinese formal treatments of architecture, human figures, birds and flowers. The first, with its compact, flattening treatment of multiple facetted planes that comprised the 'nine-perfections' palace and its Qinling mountain setting seen from a high viewpoint, appeared to be a fragment of a much larger composition. In La Peinture Chinoise the image was accompanied by a French translation of Tang poet Du Fu's verse lamenting the palace's extravagance (Chavannes, Petrucci 1914: 1-5). Tang Yin's 'Beautiful Woman' is also accompanied by poetry (by Wen Zhengming?), this time at the top right of the silk panel and praising the grace of the woman inhaling the aroma of the peonies diagonally below. That the woman is cropped at her waist suggests the image is likewise only a fragment of a larger picture - in this case a fulllength portrait. Such fragmentation and cropping was quite possibly unknown to 
the Russian modernists who would have seen the images in Apollon, yet, nevertheless, they would have appealed to their concern for fracture and abstraction, as would the balanced assymetry of the compositions and the incorporation of script.

Across such range Dmitriev discerned distinct, refined approaches to the human figure. These he supplemented with a reproduction of and note (by Apollon editor Sergey Makovskiy) on the silk scroll 'Portrait of Patriarch Qiang Mei Laozi' (Ill. 6) belonging to Sergey Shchukin. In the note Makovskiy cited Golubev for the attribution of the latter to the early Qing dynasty ( $17^{\text {th }}$ century) and considered the flattened full-frontal, full-length image (in India ink and watercolour) of an old man seated on a throne-like chair in ceremonial robes and holding a rosary as a funerary portrait: 'such portraits are usually encountered in the parts of houses dedicated to family forebears and they are venerated like icons in accordance with Confucian tradition' (Дмитриев 1912:

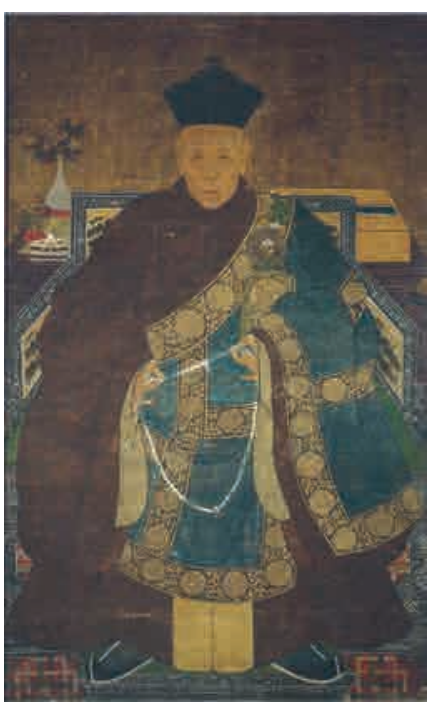

Ill. 6. Unknown artist. Portrait of Patriarch Qiang Mei Laozi.

Painted silk. $156 \times 95 \mathrm{~cm}$.

$17^{\text {th }}$ century. State Museum of Oriental Art, Moscow 23). An inscription on the painting adds further detail: 'Epoch-bearing, oldest ancestor Qiang Mei Long Brows has said farewell to the world. His journey to the abode of Yan Fu sanctum took 85 years. Four greats [elements?] must return to earth. His spirit moves westwards towards the patriarchs of Buddhism.' (Сычев 2014: 110).

Shchukin possessed at least six Chinese and Korean paintings, with this, the largest (at $156 \times 95 \mathrm{~cm}$ ) being given a significant place in the hall known as the Cézanne gallery. ${ }^{10}$ A photograph by Pavel Orlov (c. 1914) reveals it, in a frame and behind glass, hung on the same wall as a selection of French Impressionist and Post-Impressionist paintings, including a Paul Cézanne still-life, a landscape by André Derain, and six figure paintings (Ill. 7). The latter, which included portraits by Maurice Denis, Auguste Renoir and Vincent Van Gogh, featured Cézanne's 'Mardi Gras (Pierrot et Arlequin) ' and 'Man with a Pipe' as well as Henri Matisse's 'Nude. Black and Gold', all of which would seem to have been juxtaposed with the Qing portrait to stimulate visual associations. ${ }^{11}$

10 Shchukin's brother Pyotr Shchukin was also a collector of Chinese art, including porcelain and sculpture.

11 I am grateful to Shchukin collection specialist Natalya Semenova for revealing the existence of the photograph to me after I had presented an initial version of this paper in 2014 (see also Semenova 2018: 213; Semenova 2019: 178-179, 180-181, where the author mentions how the Korean portraits coincided with Shchukin's obsession with Derain). Menshikova (2016: 41) tentatively suggests Patriarch is slightly earlier than Qing, i. e. from the mid-Ming dynasty $\left(15-16^{\text {th }}\right.$ century). She confuses Dmitriev's discussion of an earlier portrait of a Chinese holy man (from artist Henri Rivière's collection, and as reproduced in Apollon and La Peinture Chinoise) with the Shchukin-owned scroll (Дмитриев 1912: 23). 


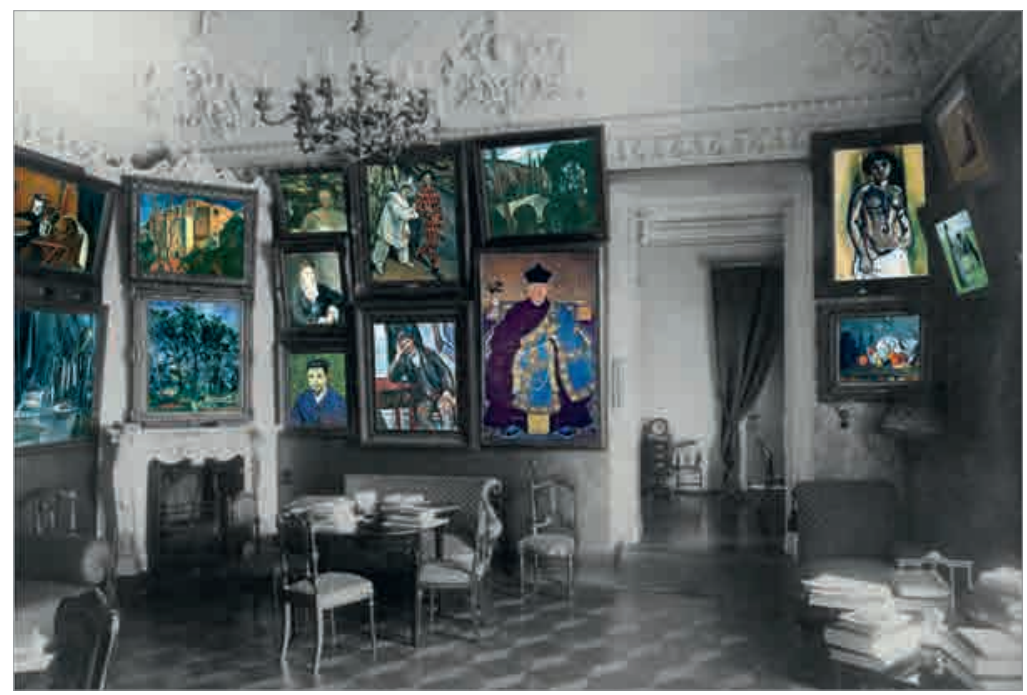

Ill. 7. Paul Orlov, Cézanne Gallery, Shchukin mansion, Moscow. Photograph. 1914 (reconstruction by Christine Delocque-Fourcaud (C) Collection Chtchoukine, Paris)

The Shchukin gallery photograph leads us to the display of Chinese art in Russia in Markov's time. Markov had discussed the beauty of the Tangut Buddhist artworks from Khara-Khoto that were exhibited in St Petersburg in early 1910 in 'Russian Secession' (Howard, Bužinska, Strother 2016: 161). And two years earlier, at the large International Art-Construction Exhibition, held in the Russian capital (May - October 1908), the pavilion of the Trans-Manchurian (Eastern Chinese) Railway, had been built in the style of a Chinese pagoda and contained photographs, some tinted, not only of railway frog crossings and platforms but also of Chinese architectural motifs that the engineers had encountered while building the line. For our purposes, particular significance can be apportioned to an exhibition of international folk prints that was mounted in a hall of the Moscow School of Painting, Sculpture and Architecture in February 1913. Entitled 'The First Exhibition of Lubki', work included was Chinese, Japanese, Buryat, Korean, Persian, Turko-Tataric, Russian, French, English, Polish, German and Hungarian. The vast majority of this graphic art was Chinese. It had been acquired in 1912 by the organiser of the exhibition, Nikolay Vinogradov (then a twenty-seven year old architecture student and revolutionary), when he had visited his family in Harbin, the new, Russian-created, urban hub of TransManchurian railway in northeastern China.

In his review of the show critic Sergey Mamontov noted the following:

The Chinese section is the most full of all. A whole series of pictures of religious subjects is striking for its resemblance to works of our Suzdal icondaubers. A set of original exemplars by employees of a school for graphic trades artists of the Celestial Empire is arranged in a special display case. They are not allowed to deviate one iota from these templates. There are some interesting little 


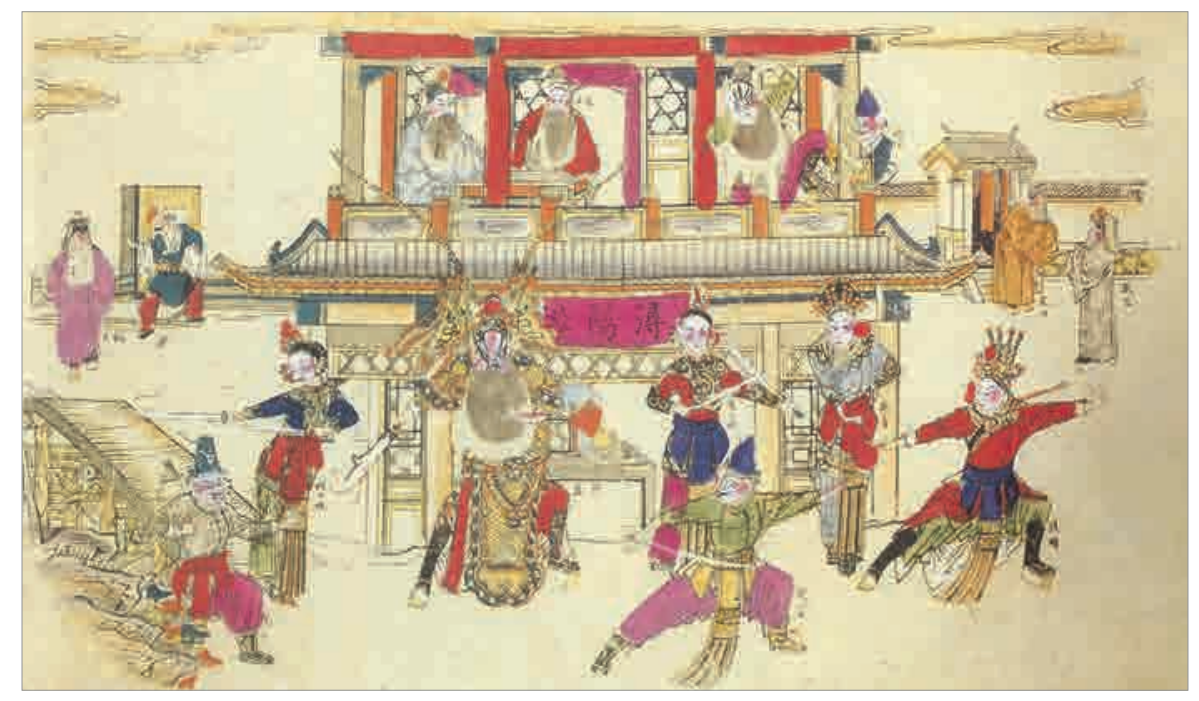

Ill. 8. Unknown artist, Xunyan Lou Tavern. Coloured xylograph. $53 \times 92 \mathrm{~cm}$. Late $19^{\text {th }}$ - early $20^{\text {th }}$ century. Elena Ovsyannikova Collection, Moscow

female figures with softly finished faces, these being created to order by itinerant street artists in southern Chinese towns. (Мамонтов 1913)

Mamontov was the son of Savva Mamontov, the founder of the Abramtsevo art colony who had actively sought a regeneration and modernisation of Russian folk traditions in the 1880s and 1890s via the input of some of the most creative Russian artists of the day. That this scion of the previous reformist generation should have discerned a formal kinship between Chinese religious prints and the relatively crude stylised late-seventeenth/early eighteenth century (and later) folk icons of Suzdal is significant, not least because the artistic enterprises of the Mamontov family were critical for the development of subsequent Russian avantgardes. Furthermore, without getting into details, his Chinese-Suzdal connection intimates a path in innovative cultural equation being advocated and taken by Markov (and his milieu).

According to Boris Riftin, who surveyed the exhibition catalogue, reviews and known surviving works, the Chinese art mainly comprised nianhua (woodblock prints) for the new year spring festival, but also included theatre, story and votive prints, e.g. of 'Door Gods' and 'The Eight Immortals' (Рифтин et al 1991: 8). One work, from Yangliuqing, one of the oldest and most revered centres of nianhua production, was a large coloured print depicting 'Xunyan Lou', an ancient tower inn overlooking the Yangtse River (Рифтин et al: Plate 107) (Ill. 8). This is the setting for a series of scenes illustrating the writing of a seditious poem, arrest and freeing of the Song dynasty outlaw Song Jiang. Derived from chapters 38 to 40 of the classic novel Water Margin (Outlaws of the Marsh) written in vernacular Chinese by Yuan dynasty author Shi Nai'an, the multiple moments in Vinogradov's print are marked by vivid yet highly limited coloration, 


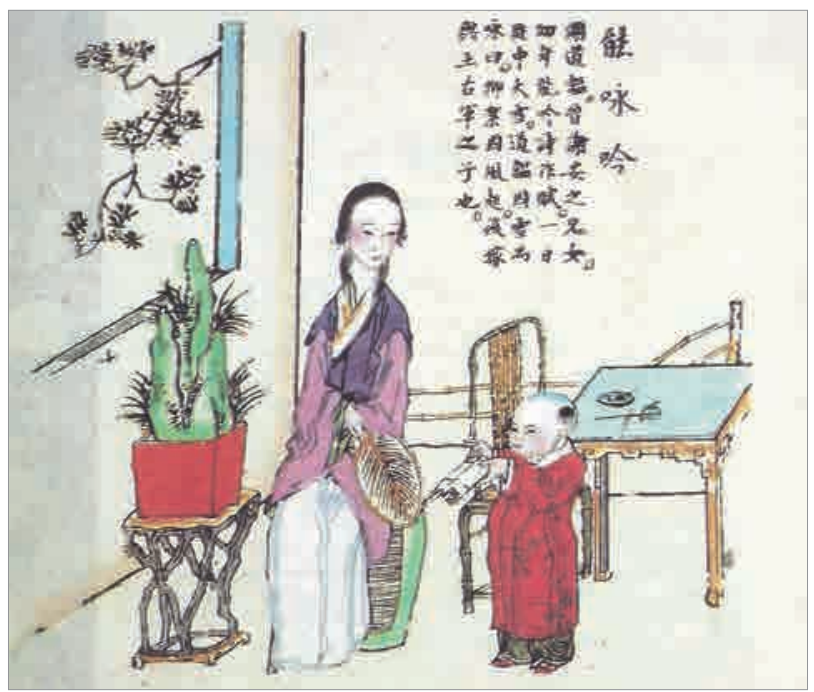

Ill. 9. Unknown artist. You can make up a Poem. Coloured xylograph. $28 \times 56 \mathrm{~cm}$. Detail. Late $19^{\text {th }}$ - early $20^{\text {th }}$ century. State Hermitage Museum, St Petersburg.

delicate linearity, dramatised poses, ambiguous space, identifying captions, and an attention to figural detail. Jane Ashton Sharp has revealed the significance of this broadsheet medium and its formal strategies for the new art of Natalya Goncharova and Mikhail Larionov, and she has done so through a brief survey of Vinogradov's exhibition and collection that hints at the place of nianhua (Sharp 2006: 153-157).

Riftin has pointed out that Vinogradov's was not the first Russian exhibition of such prints from China, it being preceded in 1898 and 1910 by exhibitions dedicated to them in St Petersburg, both being organised under the auspices of the Imperial Russian Geographic Society (Рифтин et al 1991: 1-8).12 While Markov is unlikely to have seen the first, the second was displayed in the imposing new premises of the society in the year that his activities within the Union of Youth were initiated and so may well have caught his eye. The collection was that of the young sinologist Vasiliy Alekseyev, subsequently Markov's posthumous detractor. ${ }^{13}$ One could identify any number of works for alignment with Markov's identification of Chinese creative principles but here we should just introduce the

12 Russian modernist awareness of Chinese visual art was also raised in the first issue of Apollon through Wassily Kandinsky's 'Letter from Munich'. In this the budding syncretic abstractionist praised the 'Japan und Ostasien in der Kunst' exhibition, with its twelfth century Chinese painting, for its rhythmic abstract form and colour that reflected a deeply felt 'inner sound' that was the 'sound of the human soul' (Кандинский 1909: 19-20). Given the similarities of their exegeses could Kandinsky have alerted Markov to the value to be gleaned from China? They were certainly in touch within a few years.

13 Riftin et al (Рифтин et al 1991) illustrates more than forty prints from Alekseyev's collection, the majority of these now being in the State Hermitage and the Museum of the History of Religion, St Petersburg. 
left half of 'You can give up a pear. You can make up a poem', a Yangliuqing print that illustrates poem-maxims from San Zi Jing (Three Character Classic), a Song dynasty Confucianist elementary learning text: (Рифтин et al 1991: plate 62 detail). In 'You can make up a poem' (Ill. 9) both subject and stylised execution accord with Markov's views on Chinese aesthetics. Hence we are presented with a young girl who finds willow fluff analogous to snow and a composition that combines logogram verse with a picture employing 'non-constructive' perspective, light, etc.

Vinogradov's lubki exhibition was augmented by two 'Negro sculptures' from Larionov's collection and some bronze religious statues of unknown origin belonging to Goncharova, as well as a set of 'contemporary Russian lubki' by the latter. ${ }^{14}$ Such connections, coincident as they were with Markov's articulation of the need for a revivifying 'primitive' approach for modern art, brings us to contemporary Russian visual interpretations of Chinese art. It remains an open question how far these comprise modernist chinoiserie or sinological modernism. Within 'The Russian Avant-garde, Siberia and the East' exhibition, which took place in Florence in late 2013, and its accompanying catalogue, numerous visual associations (some well-known, others less so) between early twentieth century Russian painting and Chinese art were enunciated. ${ }^{15}$ Among the works included were Ilya Mashkov's 'Lady with a Chinese Woman (Portrait of Eugenia Kirkcaldy)' (1910) in which the young Scottish art student in Moscow and her Chinese 'servant' are treated as objects, along with the accompanying still-life, deer and snake, for the artist's painterly experimentation. With the maid looking like an oversized print turned into wallpaper, this colorist chinoiserie bears much in common with that witnessed in Pyotr Konchalovskiy's 'Family Portrait with Chinese Print' (1911) where the broadsheet on the wall features a flattened and stylised Chinese boy grappling with a fish among waves.

Likewise Goncharova, who, together with Larionov, possessed a collection of Chinese folk prints, took to playing with Chinese themes and formal solutions in her painting around this time, e. g. in 'Still-Life with Chinese Print' (1908-09), 'Chinese Lubok' (early 1910s) and 'Chinoiserie' ('Kitaeska', 1912-13). With their heightened attention to Chinese technique (combined with an increasing dominance of Chinese motifs) these works appear the start of Russian sinological modernism, and a primitivist move away from the more chinoiserist-exoticist contemporary work of Alexander Benois and Nikolay Kalmakov, e.g. Benois' designs for Igor Stravinsky's opera 'Le Rossignol' (1914) and Kalmakov's 'Buddha and Chinese Maiden' (1913). As the editors of the Florence catalogue indicate: 'Goncharova turns the affected, rétro elegance of chinoiserie upside-down in her painting of that name to pinpoint the intrinsic value of the calligraphic stroke as a visual sign in Chinese art' (Bowlt, Misler, Petrova (eds.). 2013: 182).

14 From the catalogue, as cited in Sharp 2006: 155.

15 The catalogue (Bowlt, Misler, Petrova eds. 2013) reproduces and contextualises all of the paintings discussed in this paragraph and the next. They are in the collections of the Russian Museum, St Petersburg, and Tretyakov Gallery, Moscow. 

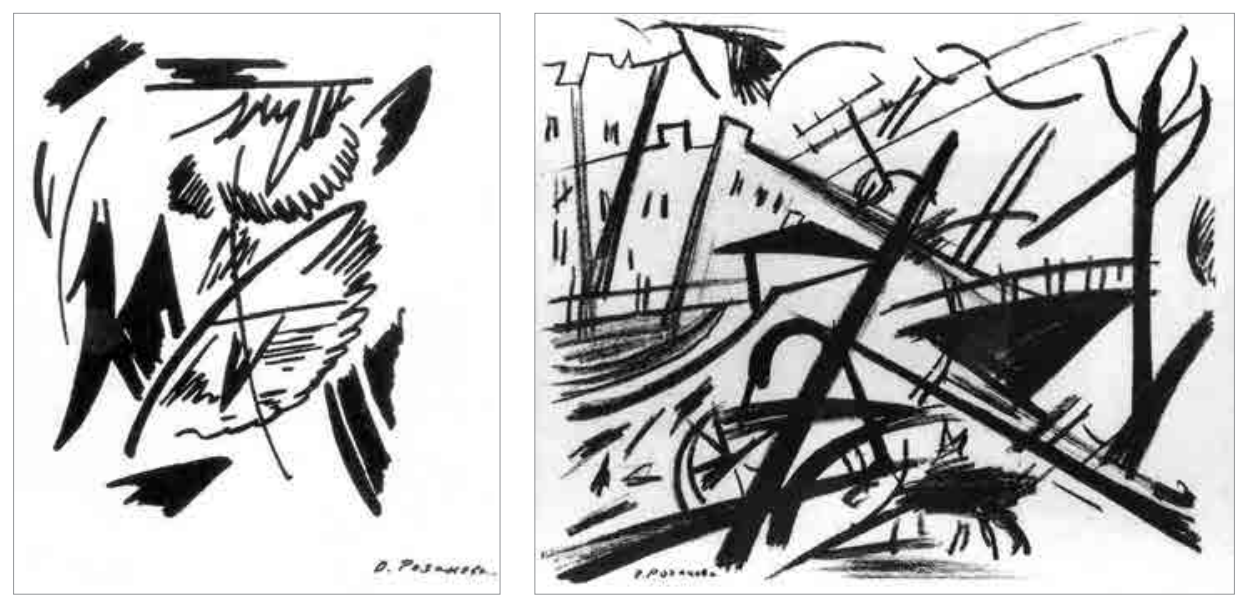

Ills. 10, 11. Olga Rozanova. Drawing. Soyuz Molodezhi. 3, 1913

Russian sinological modernism, with a discernible admixture of Nipponesque flair and primitivist daring, was to be furthered in the highly abstract socalled cubo-futurist drawings that Goncharova and Larionov, as well as their Union of Youth colleagues Olga Rozanova and Iosif Shkolnik, were to make for contemporary avant-garde booklets and periodicals, e. g. Gardeners over the Vines [Вертоградари над лозами] (Goncharova and Sergey Bobrov, 1913), OldTime Love [Старинная любовь] and Pomade [Помада] (Larionov and Aleksey Kruchenykh, 1912 and 1913) and Soyuz Molodezhi [Союз молодежи] (Rozanova and Shkolnik, No. 3, 1913) (Ills. 10-12). In all of these a relationship with Chinese ink landscapes and calligraphy is felt, as if the oriental work had provided a departure point. Ultimately, we can also draw into this sinological modernist web, typical abstract works by Kandinsky and Constructivist assemblages by artists such as Gabo, with the two utilised by Sullivan (1997: 224-248) for indications of their distinctive metaphysical and formal 'Far Eastern' sensitivities, serving as adequate examples: i.e. Kandinsky's 'Light Picture No. 188' (1913) and Gabo's 'Construction in Space with Balance on Two Points' (1925).

\section{To Conclude... or Not}

It would seem to go against the grain of the creative principles discerned in Chinese art by Markov and his contemporaries to provide a rationalised rounding off of this enquiry. That said, we have shown that an appreciation of a variety of Chinese aesthetics in diverse media both informed and helped develop Russian modernist language. The turn east was imaginative, unrestricted by scientific or linguistic literalness. In many ways it was led by the explanatory examples of Markov, these consistent with and followed by a wide range of visual practice demonstrated by artists with whom he was associated, not least leading members of/contributors to his Union of Youth group. Despite the wealth 


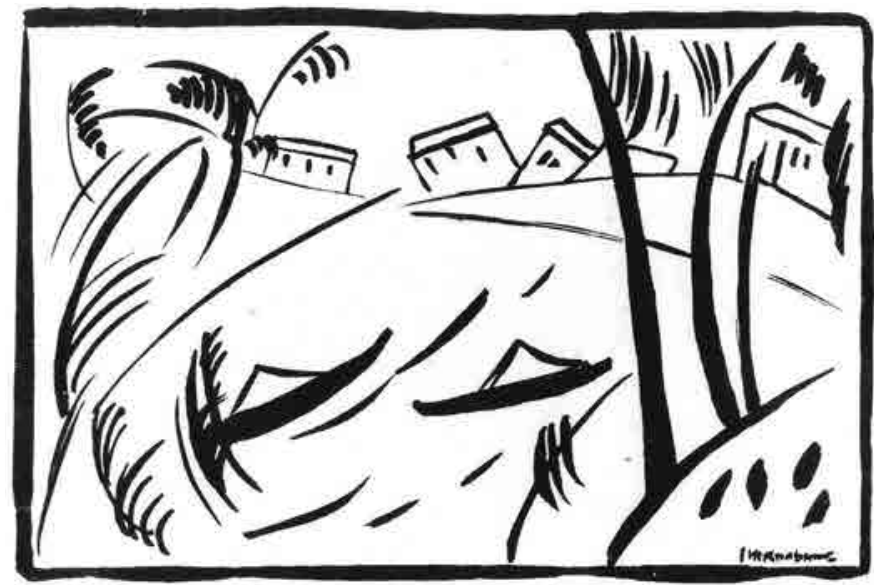

Ills. 12. Olga Rozanova. Drawing. Soyuz Molodezhi. 3, 1913

of enquiry into Russian modernism, it seems odd that this particular relationship has hitherto been so little focused on. Hence this piece is an attempt to draw it out of the shadows to allow the 'pearl curtain' to be raised and 'pierced by sunbeams' or 'moonlight gushing'. With this in mind, let us end with the discombobulated, dadaesque online Google translation into English of Li Bai's 'Staircase in the Moonlight' (or 'Yu-chieh complain'), as it appeared on my computer screen in 2014 (Ill. 13):

Yu-chieh Health and Towers

night long socks invade Romania

but under crystal curtain

exquisite look Moon

Would Markov, given his principles of non-constructiveness, chance, 'noise', free creativity and material enslavement, have approved? Who knows.

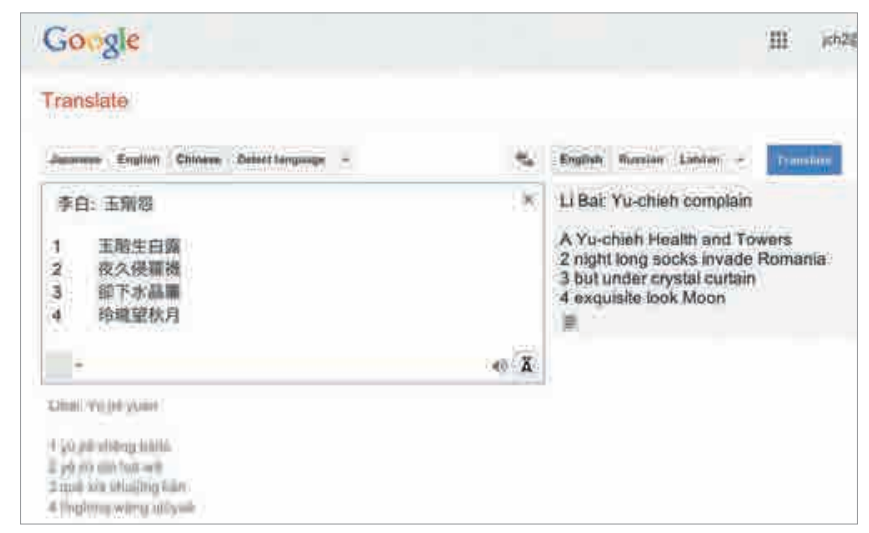

I1l. 13. Google Translate. Yu-chieh Health and Towers. 2014 


\section{LITERATURE}

Alekseev Vasilij. "Predislovie”. Shchuckij Yulian. Dal'nee ekho: Antologiya kitaiskoj liriki (VII$I X v v$.) [Moskva-Peterburg: Gosudarstvennoe Izdatel'stvo, 1923]. Sankt-Peterburg: Peterburgskoe Vostokovedenie, 2000: 25-36.

Anonymous. "WAYS — Li Po's Jade Stairs Lament”. http://poetrychina.net/translation/jade_ stairs (accessed 7.6.2021).

Baldassari Anne. Icons of Modern Art. The Shchukin Collection. Paris: Gallimard, 2016.

Bethge Hans. Die Chinesische Flöte. Leipzig: Insel, 1907.

Binyon Laurence. The Flight of the Dragon: an essay on the theory and practice of art in China and Japan. London: John Murray, 1911.

Bobrov Sergej, Goncharova Nataliya. Vertogradari nad lozami. Moskva: Lirika, 1913.

Borel' Genri. Neprotivlenie. Sankt-Peterburg: B.M. Vol'f, 1913.

Bowlt John, Misler Nicoletta, Petrova Evgenia (eds.). The Russian Avant-garde, Siberia and the East. Milan: Skira, 2013.

Bradbury Steve. "Li Bai. The Jeweled Stairs' Grievance”. https://www.cipherjournal.com/html/ bradbury_stairs.html (accessed 7.6.2021).

Chavannes Edouard, Petrucci Raphaël. La Peinture Chinoise au Musée Cernuschi Avril-Juin 1912. Bruxelles, Paris: G. Van Oest, 1914.

Dmitriev Vsevolod. “Kitajskaya real'nost"'. Apollon 5 (1914): 21-25.

Douglas Charlotte. Swans of other Worlds: Kazimir Malevich and the Origins of Abstraction in Russia. Ann Arbor: University of Michigan Press, 1980.

Egor'ev Vyacheslav, Markov Vladimir. Svirel' Kitaya. Sankt-Peterburg: Soyuz molodezhi, 1914.

Gladkij Pavel. Kitajskoe iskusstvo. Istoricheskoe vvedenie. Harbin: Tipografiya Kitajskoj Vostochnoj zheleznoj dorogi, 1915.

Grube Wilhelm. Geschichte der Chinesischen Litteratur. Leipzig: C. F. Amelangs, 1902.

Grube Vil'gel'm. Duhovnaya kul'tura Kitaya. Literatura, religiya, kul't. Sankt-Peterburg: Brokgauz-Efron, 1912.

Gumilev Nikolaj. Farforovyj pavil'on. Sankt-Peterburg: Giperborej, 1918.

Howard Jeremy, Bužinska Irēna, Strother Z.S. Vladimir Markov and Russian Primitivism: A Charter for the Avant-Garde, Abingdon: Routledge, 2016.

Howard Jeremy. The Union of Youth. Manchester: Manchester University Press, 1992.

Kandinskij Vasilij. "Pis'mo iz Myunhena". Apollon 1 (1909): 17-20.

Kovtun Evgenij. “Iz istorii russkogo avangarda (P. N. Filonov) ". Ezhegodnik rukopisnogo otdela pushkinskogo doma na 1977 god, Leningrad: Nauka, 1979: 216-226.

Kruchenyh Aleksej, Larionov Mihail. Starinnaya lyubov'. Moskva: Kuz'min i Dolinskij, 1912.

Kruchenyh Aleksej, Larionov Mihail. Pomada. Moskva: Kuz'min i Dolinskij, 1913.

Laing Ellen Johnston. "Boris Riftin and Chinese Popular Woodblock Prints as Sources on Traditional Chinese Theater". Chinoperl Papers 29 (2010): 183-208.

Menshikova Maria. "Chinese Portrait from the Sergei Shchukin Collection". Hermitage Magazine 23 (2016): 40-41.

Mamontov Sergej. "Vystavka lubochnyh kartin raznyh narodov i epoh". Russkoe slovo. 43, 21.02.1913: 15.

Markov Vladimir. Faktura. Sankt-Peterburg: Soyuz molodezhi, 1914.

Pyaseckij Pavel. Puteshestvie po Kitayu v 1874-1875 gg. (2 tom). Sankt-Peterburg: M. Stasyulevich, 1880-1881.

Pound Ezra. Cathay. London: Elkin Mathews, 1915.

Riftin Boris, Van Shucun', Tun Czinhanya. Redkie kitajskie narodnye kartiny iz sovetskih sobranij. Leningrad: Avrora, 1991.

Sharp Jane Ashton. Russian Modernism between East and West. Natal'ia Goncharova and the Moscow Avant-Garde. Cambridge: Cambridge University Press, 2006.

Shchuckij Yulian. "Li Bo". Vostok. ZHurnal literatury, nauki i iskusstva 1 (1922): 43.

Semenova Natalya. The Collector. The Story of Sergei Shchukin and His Lost Masterpieces. New Haven: Yale University Press, 2018.

Semenova Natalya. Shchukin. Biography of a Collection. Moskva Slovo, 2019.

Smirnov Il'ya. "Ob odnom stihotvorenii Li Bo". Inostrannaya literatura 2 (2007): 275-288. 
Soyuz molodezhi. 1-4 (1912-1914).

Staff Leopold, Fletnia Chińska. Warsaw: J. Mortkowicz, 1922.

Strala A. "Voldemāra Matveja atzinas par kiniešu dzeju" [Voldemars Matvejs' Opinion of Chinese Poetry], Karogs 7 (1988): 184-185.

Sullivan Michael. The Meeting of Eastern and Western Art. Berkeley: University of California Press, 1997.

Sychev V. L. Klassicheskaya zhivopis' Kitaya v sobranii Gosudarstvennogo muzeya Vostoka. Moskva: Gosudarstvennyj muzej Vostoka, 2014.

Алексеев Василий. «Предисловие». Щуцкий Юлиан. Дальнее эхо: Антология китайской лирики (VII-IX вв.) [Москва-Петербург: Государственное Издательство, 1923]. СанктПетербург: Петербургское Востоковедение, 2000: 25-36.

Бобров Сергей, Гончарова Наталия. Вертоградари над лозами. Москва: Лирика, 1913.

Борель Генри. Непротивление. Санкт-Петербург: Б. М. Вольф, 1913.

Гладкий Павел. Китайское искусство. Историческое введение. Харбин: Типография Китайской Восточной железной дороги, 1915.

Грубе Вильгельм. Духовная культура Китая. Литература, религия, культ. Санкт-Петербург: Брокгауз-Ефрон, 1912.

Гумилев Николай. Фарфоровый павильон. Санкт -Петербург: Гиперборей, 1918.

Дмитриев Всеволод. «Китайская реальность». Аполлон 5 (1914): 21-25.

Егорьев Вячеслав, Марков Владимир. Свирель китая. Санкт -Петербург: Союз молодежи, 1914.

Кандинский Василий. «Письмо из Мюнхена». Аполлон 1 (1909): 17-20.

Ковтун Евгений. «Из истории русского авангарда (П. Н. Филонов)». Ежегодник рукописного отдела пушкинского дома на 1977 год. Ленинград: Наука, 1979: 216-226.

Крученых Алексей, Ларионов Михаил. Старинная любовь. Москва: Кузьмин и Долинский, 1912.

Крученых Алексей, Ларионов Михаил. Помада. Москва: Кузьмин и Долинский, 1913.

Мамонтов Сергей. «Выставка лубочных картин разных народов и эпох». Русское слово. 43, 21.02.1913: 15 .

Марков Владимир. Фактура. Санкт-Петербург: Союз молодежи, 1914.

Пясецкий Павел. Путешествие по Китаю в 1874-1875 г2. (2 том). Санкт-Петербург: М. Стасюлевич, $1880-1881$.

Рифтин Борис, Ван Шуцунь, Тун Цзинханя. Редкие китайские народные картины из советских собраний. Ленинград: Аврора, 1991.

Смирнов Илья. «Об одном стихотворении Ли Бо». Иностранная литература 2 (2007): $275-288$.

Союз молодежи. 1-4 (1912-1914).

Сычев В. Л. Классическая живопись Китая в собрании Государственного музея Востока. Москва: Государственный музей Востока, 2014.

Щуцкий Юлиан. «Ли Бо». Восток. Журнал литературы, науки и искусства 1 (1922): 43.

Џереми Хауард

\section{СТЕПЕНИШТЕ У МЕСЕЧИНИ ВЛАДИМИРА МАРКОВА: ПИТАҢА РУСКОГ МОДЕРНИСТИЧКОГ СИНОИЗМА И СИНОЛОШКОГ МОДЕРНИЗМА}

Резиме

Владимир Марков (Voldemārs Matvejs) (1877-1914) избегавао је тенденцију „-изма“ у свом писању. Ипак, можемо га сматрати оријенталистом, примитивистом, архаистом и модернистом. Сви његови објављени есеји односе се на кинеску уметност и његово интересовање за кинеску естетику, која представља предмет рада. Полазећи од чињеница које 
се обрађују у Кинеској флаути [Svirel' Kitaya] (1914), овај рад истовремено анализира Марковљеву интерпретацију и примере уметничких принципа, који се у његовим другим студијама квалификују као кинески. Стога полазимо од његовог интересовања за поетску структуру и слободну форму, долазећи до „неконструисаности“, „случајног“, „рафинираног“, имитације, „слободног стварања“, спајања материјала, симбола и боје. У суштини, они садрже аргумент за све начине реформисања европске уметности путем детаљне анализе уметничких предмета и онога што обухвата само стварање. Док је Марковљев поглед глобалан, што, на пример, откривају његова истраживања о афричкој уметности, уметности Океаније и Северне Азије, и док он истовремено може бити описан као византолог због његовог интересовања за иконе, ови атрибути се налазе по страни у односу на оно што видимо као модернистички кинески стил и синолошки модернизам. Наше истраживање испитује како се Марковљев приступ може довести у контекст с достигнућима у кинеском стилу и синологији почетком XX века, а самим тим и у однос с интерпретативним радовима, на пример, Василија Алексејева, Николаја Виноградова и Леополда Стафа, као и у однос са стваралаштвом многих руских визуелних уметника почетком XX века.

Кључне рече: Владимир Марков, кинеска поезија, синологија, кинески стил, модернизам. 